\title{
Recent developments in functional bakery products and the impact of baking on active ingredients
}

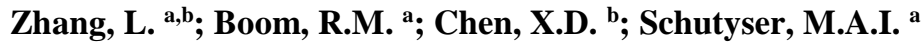 \\ ${ }^{a}$ Laboratory of Food Process Engineering, Wageningen University, Wageningen, the Netherlands. \\ b School of Chemical and Environmental Engineering, Soochow University, Suzhou, China. \\ *E-mail of the corresponding author: maarten.schutyser@wur.nl
}

\begin{abstract}
(100 words)
Active ingredients can be supplemented into a bakery product to produce functional food. However, the preservation of the functionality of these active ingredients during baking remains a challenge for food industry. A deeper understanding of the underlying interactions between functionality and baking is highly desired for developing innovative functional bakery products with significant health benefits and high product quality. In this work, recent advances in the development of functional bakery products are reviewed. The interactions between the baking process and the functionality of the supplemented active ingredients are discussed and the perspective of future research is addressed.
\end{abstract}

Keywords: baking; active ingredients; probiotics; inactivation kinetics; functional food 


\section{Introduction}

A functional food can be defined as a modified food or food ingredient that may provide a health benefit to the consumer beyond its basic nutrients. Bakery products can be fortified with health-promoting active ingredients to produce non-dairy-based functional food. The viability of the active ingredients such as probiotics in the final products should be sufficient to confer beneficial influence on consumer health. However, for baking process it is a challenge to maintain the functionality of these heat-sensitive active ingredients as high temperatures are involved.

This review aims to illustrate recent advances and challenges in the development of functional bakery products. The interactions between the baking process and the funcationality of the active ingredients are discussed, as well as new technologies such as microencapsulation to preserve the active ingredients during baking. Manufacturing of functional bakery products of good quality and sufficient health-promoting properties leads to interesting research questions and the perspective of future research is addressed.

\section{Recent advances in the development of fuctional bakery products}

The father of modern medicine Hippocrates declared 2500 years ago that food intake may be beneficial to health: "Let food be thy medicine and medicine be thy food." In modern food industry, a new food category called "functional foods" emerged as a result of the increasing awareness of the link between personal health \& well-being and diet. To date, there is no unitary accepted definition for functional foods, nevertheless three main concepts are involved in most of the proposed definitions in literature, i.e., health benefits, nutritional functions and technological processes ${ }^{1}$. Among these concepts, 'technological processes' refer to i) the development of functional foods by optimizing traditional food processing technologies, e.g. fortification of foods with dietary fibre; ii) technologies designed to prevent the deterioration of active ingredients, e.g. microencapsulation; iii) technologies aimed to design personalized functional foods, e.g. application of nutrigenomics; 3D food printing. To simplify, functional foods can be defined as modified food or food ingredients that can provide health benefits to the consumers beyond its basic nutrients.

Functional foods introduced into the market include for example beverages, dairy products, confectionery products, bakery products and breakfast cereals ${ }^{2}$. The category of functional bakery products is newer and received increasing attention in scientific studies. Bakery products are not only nutritious plant-based foods containing macronutrients (e.g. starch and dietary fibre) and micronutrients (e.g. antioxidants and minerals), the transportation and storage of bakery products is also less demanding compared to liquid-form products such as yoghurt. In addition, the worldwide consumption of baked goods on a daily basis makes 
these products interesting to serve as potential vehicles to deliver health-promoting ingredients to the human diet.

Table 1 lists some recent studies of functional bakery products with a special focus on bread which is one of the most-consumed staple foods. The main active ingredients supplemented to bakery goods include probiotics and prebiotics (dietary fibres), antioxidants and phenolic compounds ${ }^{3}$. Other functional ingredients are oils and lipids, minerals and salts, and vitamins ${ }^{2}$. Among these ingredients, probiotics and prebiotics are important in human nutrition because of their influences on the gastrointestinal (GI) microbiota. Probiotics are defined as 'live microorganisms which confer a health benefit on the host when administered in adequate amounts' ${ }^{4}$. Prebiotics are short chain carbohydrates which are non-digestible by digestive enzymes in the upper GI tract of humans, but are 'consumed' selectively by some types of bacteria (typically bifidobacteria and/or lactobacilli). Prebiotics can therefore enhance the activity of those beneficial bacteria ${ }^{5}$. The alleged health-promoting benefits of the aforementioned functional bakery products are diverse, e.g. reducing serum cholesterol and blood pressure, reducing the risk of coronary heart diseases, lowering the glycaemic response after food consumption, treating human intestinal barrier dysfunctions ${ }^{6-10}$.

Table 1. An overview of scientific studies focusing on functional bakery products.

\begin{tabular}{|c|c|c|c|c|}
\hline Ingredient & Product & $\begin{array}{l}\text { Incorporation } \\
\text { strategy }\end{array}$ & Baking condition & Functionality \\
\hline \multicolumn{5}{|l|}{ Probiotics } \\
\hline $\begin{array}{l}\text { Lactobacillus } \\
\text { rhamnosus R011 } \\
11\end{array}$ & biscuit & $\begin{array}{l}\text { mix microentrapped } \\
\text { cells in whey protein } \\
\text { isolate into dough }\end{array}$ & $\begin{array}{l}\text { baked at } 280^{\circ} \mathrm{C} \text { for } \\
5 \text { min }\end{array}$ & $\begin{array}{lr}4.5 \times 10^{5} & \mathrm{CFU} / \mathrm{g} \\
\text { (initial } & \text { viability } \\
1.3 \times 10^{7} \mathrm{CFU} / \mathrm{g} \text { ) }\end{array}$ \\
\hline $\begin{array}{l}\text { Lactobacillus } \\
\text { acidophilus }^{12}\end{array}$ & bread & $\begin{array}{l}\text { apply edible coating } \\
\text { layers onto the surface } \\
\text { of part-baked bread }\end{array}$ & $\begin{array}{l}\text { baked off at } 180^{\circ} \mathrm{C} \\
\text { for } 16 \mathrm{~min}\end{array}$ & $\begin{array}{l}\sim 7 \quad \log \text { CFU/70 g } \\
\text { bread }\end{array}$ \\
\hline Lactobacillus & chocolate & supplement cells & $70 \mathrm{~g}$ dough; frozen & $\sim 3-6 \quad \log \quad \mathrm{CFU} / \mathrm{g}$ \\
\hline $\begin{array}{ll}\text { reuteri } & \text { DSM } \\
17938^{13} & \end{array}$ & Soufflé & $\begin{array}{l}\text { microcapsules into } \\
\text { dough }\end{array}$ & $\begin{array}{l}\text { at }-18{ }^{\circ} \mathrm{C} ; 2 \quad \mathrm{~h} ; \\
\text { baked at } 180{ }^{\circ} \mathrm{C} \text {; } \\
10 \mathrm{~min}\end{array}$ & sample from core \\
\hline $\begin{array}{l}\text { Bifidobacterium } \\
\text { lactis Bb12 }{ }^{14}\end{array}$ & bread & $\begin{array}{l}\text { mix cell suspension } \\
\text { into dough }\end{array}$ & $\begin{array}{l}60 \mathrm{~g} \text { dough; baked } \\
\text { at } 165,185 \text { or } 205\end{array}$ & $\begin{array}{l}\sim 2-3 \text { log } \quad \text { CFU/g } \\
\text { (initial viable counts }\end{array}$ \\
\hline & & & ${ }^{\circ} \mathrm{C}$ for $12 \mathrm{~min}$ & $\begin{array}{l}\text { in dough } 2.1 \times 10^{6} \\
\mathrm{CFU} / \mathrm{g})\end{array}$ \\
\hline $\begin{array}{l}\text { Lactobacillus } \\
\text { rhamnosus GG } \\
15\end{array}$ & bread & $\begin{array}{lr}\text { apply probiotic } \\
\text { containing } \\
\text { solution on the surface }\end{array}$ & $\begin{array}{l}\text { air dry the } \\
\text { prebaked bread at } \\
60{ }^{\circ} \mathrm{C} ; 10 \mathrm{~min} \text { or }\end{array}$ & $\begin{array}{l}\text { 7.6-9.0 } \log \text { CFU/30- } \\
40 \text { g bread slice }\end{array}$ \\
\hline
\end{tabular}




$$
\text { of prebaked pan bread } 180{ }^{\circ} \mathrm{C} ; 2 \mathrm{~min}
$$

(Continued)

\begin{tabular}{|c|c|c|c|c|}
\hline $\begin{array}{l}\text { Bacillus } \\
\text { coagulans } \\
\text { MTCC } 5856^{16}\end{array}$ & muffin & $\begin{array}{lr}\text { mix } & \text { spray-dried } \\
\text { bacteria } & \text { powder into } \\
\text { batter } & \end{array}$ & $\begin{array}{l}\text { baked at } 205{ }^{\circ} \mathrm{C} \text { for } \\
20-25 \text { min }\end{array}$ & $\begin{array}{l}7.14 \log \mathrm{CFU} / \mathrm{g} \text { (initial } \\
\text { viable counts in batter } \\
6.99 \log \mathrm{CFU} / \mathrm{g} \text { ) }\end{array}$ \\
\hline \multicolumn{5}{|l|}{ Prebiotics } \\
\hline $\begin{array}{l}\text { carob } \\
\text { fibre/inulin/pea } \\
\text { fibre }^{17}\end{array}$ & bread & add 3\% fibre to dough & $\begin{array}{l}100 \mathrm{~g} \text { dough; baked } \\
\text { at } 190{ }^{\circ} \mathrm{C} \text { for } 20 \\
\text { min }\end{array}$ & $\begin{array}{l}\text { total dietary fibre in } \\
\text { bread: carob fibre } 5.06 \\
\% \text {; inulin } 5.14 \% \text {; pea } \\
\text { fibre } 5.38 \% \text {; }\end{array}$ \\
\hline $\begin{array}{l}\beta \text {-glucans \& } \\
\text { arabinoxylans } \\
18\end{array}$ & flat bread & $\begin{array}{l}\text { substitute wheat flour } \\
\text { with } 20 \% \text { barley fibre- } \\
\text { rich-fractions }\end{array}$ & $\begin{array}{l}\text { diameter of circular } \\
\text { dough sheet } 20 \mathrm{~cm} \text {; } \\
\text { baked at } 540{ }^{\circ} \mathrm{C} \text { for } \\
70 \mathrm{~s}\end{array}$ & $\begin{array}{l}\text { total } \beta \text {-glucans } 3.0 \mathrm{~g} \text {, } \\
\text { arabinoxylans } 4.2 \mathrm{~g} \\
\text { per flat bread }\end{array}$ \\
\hline $\begin{array}{l}\text { hemicellulose B } \\
19\end{array}$ & bread & $\begin{array}{l}\text { add hemicellulose B to } \\
\text { dough }\end{array}$ & $\begin{array}{l}\text { baked at } 200{ }^{\circ} \mathrm{C} \text {, } \\
\text { baking time N/A }\end{array}$ & $\begin{array}{l}3.87 \% \text { dm dietary } \\
\text { fibre in baked bread }\end{array}$ \\
\hline $\begin{array}{l}\text { bacterial } \\
\text { nanocellulose } \\
(\mathrm{BNC})^{20}\end{array}$ & bread & $\begin{array}{l}\text { disperse BNC gel in } \\
\text { water and mix with } \\
\text { other ingredients }\end{array}$ & $\begin{array}{l}70 \mathrm{~g} \text { dough; baked } \\
\text { at } 195{ }^{\circ} \mathrm{C} \text { for } 23 \\
\text { min }\end{array}$ & N/A \\
\hline \multicolumn{5}{|l|}{ Others } \\
\hline tea catechins ${ }^{21}$ & bread & mix green tea extract & at $215^{\circ} \mathrm{C}$ for & tea catechins content: \\
\hline $\begin{array}{l}\text { phenolic } \\
\text { antioxidants }{ }^{22}\end{array}$ & bread & $\begin{array}{l}\text { into dough } \\
\text { substitute wheat flour } \\
\text { with fruit phenolic } \\
\text { extracts }\end{array}$ & $\begin{array}{l}11 \mathrm{~min} \\
\text { baked at } 155^{\circ} \mathrm{C} \text { for } \\
60 \mathrm{~min}\end{array}$ & $\begin{array}{l}0.53 \mathrm{mg} / \mathrm{g} \text { bread } \\
\text { the phenolic recovery } \\
\text { ranged from } 9 \% \text { to } 39 \\
\% \text {; total antioxidant } \\
\text { activity increased }\end{array}$ \\
\hline anthocyanin 23 & bread & $\begin{array}{l}\text { mix anthocyanin-rich } \\
\text { black rice extract } \\
\text { powder into dough }\end{array}$ & $\begin{array}{l}50 \mathrm{~g} \text { dough; baked } \\
\text { at } 200^{\circ} \mathrm{C} \text { for } 8 \mathrm{~min}\end{array}$ & $\begin{array}{l}79 \% \text { of cyanidin-3- } \\
\text { glucoside was retained } \\
\text { in bread crumb after } \\
\text { baking }\end{array}$ \\
\hline
\end{tabular}

\section{Bread baking process}

Bread is one of the most-consumed staple foods worldwide. Bread making is a complex process involving dough mixing, proofing (i.e., fermentation), baking and cooling. Among these steps, baking is of great importance because heat and mass transfer occurs simultaneously and interdependently inside the dough during baking, along with a series of physical and chemical changes, e.g. water evaporation, gas cell expansion, starch gelatinization, protein coagulation, dough-crumb transition and crust formation ${ }^{24}$. These changes are dominated by heat and mass transfer mechanisms inside the oven chamber as well as in the product, and interact in a complex manner, which significantly influence the 
product quality. A deeper understanding of the bread baking process is necessary to better control the quality of the final products.

During baking, the heat transport in the dough is dominated by the classic 'evaporationcondensation' mechanism ${ }^{25}$. Hence, the temperature in the crumb reaches a plateau of 100 ${ }^{\circ} \mathrm{C}$ while the moisture content remains similar to that of the dough (40 w/w\%); the temperature in the crust keeps increasing to the oven temperature (if the baking time is long enough) and the moisture content reduces more significantly (to $20 \mathrm{w} / \mathrm{w} \%$ ) compared to the crumb ${ }^{26}$. These distinct temperature and moisture content histories in the inner part and the outer layer of the dough result in bread with unique macroscopic features, i.e., soft and porous crumb and crispy and dense crust. In addition, the brown colour of the crust and the flavour/aroma of the bread are formed during baking due to the Maillard reactions.

\section{Factors influence the functionality of active ingredients}

The development of functional bread is challenging for the food industry because active ingredients may fully or partly lose their bioactivity or bioavailability during manufacturing due to either the high baking temperature or their interaction with other ingredients, e.g. decreased bioavailability of water-extractable arabinoxylan in bread due to ferulic acidprotein cross-links ${ }^{27}$. Therefore, it is important to investigate the interactions between the bread making process and the addition of active ingredients.

On the one hand, the baking process can influence the bioactivity of heat-sensitive ingredients supplemented to bread e.g. probiotics ${ }^{14}$. Although certain probiotic strains (i.e., Bacillus coagulans) may show high heat resistance due to their ability to form spores (see Table 1$)^{16}$, several strategies have been investigated to preserve other probiotic strains (i.e., lactic acid bacteria) under stressful conditions, e.g. micro-entrapment or encapsulation, edible film, coatings, and micro-beads ${ }^{28-30}$. However, application of these technologies may alter quality-attributes of bread. For example, starch based coatings containing probiotics changed the crispness of the bread crust ${ }^{12}$. Nevertheless, data available for the wide application of microencapsulation of active compounds in thermal-processed foods are still rare ${ }^{31}$. Furthermore, a recent study on the inactivation kinetics of Lactobacillus plantarum showed that the moisture content of the bread matrix influenced the survial of the embedded bacteria ${ }^{26}$. The survival of this bacterium after baking appeared higher in the crust compared to the crumb for certain balking conditions, which was attributed to the lower moisture content and denser matrix structure in the crust. New strategies to enhance survival of probiotics during baking could therefore benefit by lowering moisture content of the close environment in which the cells are embedded, e.g. via encapsulation or embedded in a thin dried film at the surface of the bread. 
On the other hand, incorporation of active ingredients into bread can influence the product quality in either a positive or a negative manner. For example, sourdough fermentation can produce bread with increased specific volume and softer crumb, and some of the added lactic acid bacteria (LAB) produce metabolites with antimicrobial activity, which prolong the shelf-life of bread ${ }^{32-34}$. However, supplementation of some other active ingredients can compromise the organoleptic properties of the products, therefore the modern food industry is seeking for techniques to resolve this problem ${ }^{35}$. For example, encapsulation technology is employed to reduce off-flavours caused by the incorporation of omega- 3 fatty acids ${ }^{36}$. Another example is that the substitution of wheat flour with fibre-rich-fractions negatively influences the aesthetic properties of the bread (e.g. dark discolouration, harder crumb with lower loaf volume) ${ }^{37}$, which consequently lowers the acceptance of the fortified bread by consumers ${ }^{38}$. In this context, enzymatic pre-treatment of the fibre-rich-fractions might be done to modify their baking properties ${ }^{39}$.

\section{Conclusion and future perspectives}

To develop functional bread that contains sufficient active ingredients without compromising product quality, systematic study on the interactions between the functional ingredients and the baking process is of great importance. Several questions for furture research are identified: i) develop kinetic models for the inactivation of active ingredients during baking based on experimental data, which can be coupled to heat \& mass transfer models of baking. The combined model may be used to optimize the baking process to better retain the functionality of active ingredients; ii) further explore the encapsulation of the active ingredients to enhance their resistance against moist-heat during baking; iii) investigate the functionality of the active ingredients during digestion, and the healthpromoting properties of those ingredients in clinical trials.

\section{References}

[1] Bigliardi B, Galati F. Innovation trends in the food industry: The case of functional foods. Trends in Food Science and Technology. 2013;31(2):118-129.

[2] Pinto D, Castro I, Vicente A, Bourbon AI, Cerqueira MA. Chapter 25: Functional Bakery Products: An Overview and Future Perspectives. In: Zhou W, Hui YH, De Leyn I, et al., eds. Bakery Products Science and Technology: Second Edition.; 2014:431-452.

[3] Dziki D. Current trends in the enhancement of antioxidant activity of wheat bread by the addition of plant materials rich in phenolic compounds. Trends in Food Science and Technology. 2014;40:48-61.

[4] FAO/WHO. Guidelines for the Evaluation of Probiotics in Food. Food and Agricultural Organization of the United Nations and World Health Organization Working Group Report. London Ontario, Canada; 2002.

[5] Al-Sheraji SH, Ismail A, Yazid M, Mustafa S, Yusof RM, Hassan FA. Prebiotics as functional foods : A review. Journal of Function Foods 2013;5(4):1542-1553.

[6] Korem T, Zeevi D, Zmora N, et al. Bread affects clinical parameters and induces gut 
microbiome-associated personal glycemic responses. Cell Metabolism. 2017;25(6):1243-1253.

[7] Aleixandre A, Miguel M. Dietary fiber and blood pressure control. Food \& Function 2016;7(7):1864.

[8] Quirós-Sauceda AE, Palafox-Carlos H, Sáyago-Ayerdi SG, et al. Dietary fiber and phenolic compounds as functional ingredients: interaction and possible effect after ingestion. Food \& Function. 2014;5(6):1063.

[9] Brownlee IA, Chater PI, Pearson JP, Wilcox MD. Dietary fibre and weight loss: Where are we now? Food Hydrocolloids. 2016:(In press).

[10] Zubillaga M, Weill R, Postaire E, Goldman C, Caro R, Boccio J. Effect of probiotics and functional foods and their use in different diseases. Nutrition Research. 2001;21(3):569-579.

[11] Reid AA, Champagne CP, Gardner N, Fustier P, Vuillemard JC. Survival in food systems of Lactobacillus rhamnosus R011 microentrapped in whey protein gel particles. Journal of Food Science. 2007;72(1):31-37.

[12] Altamirano-Fortoul R, Moreno-Terrazas R, Quezada-Gallo A, Rosell CM. Viability of some probiotic coatings in bread and its effect on the crust mechanical properties. Food Hydrocolloids. 2012;29(1):166-174.

[13] Malmo C, La Storia A, Mauriello G. Microencapsulation of Lactobacillus reuteri DSM 17938 Cells Coated in Alginate Beads with Chitosan by Spray Drying to Use as a Probiotic Cell in a Chocolate Soufflé. Food Bioprocess Technology. 2013;6(3):795-805.

[14] Zhang L, Huang S, Ananingsih VK, Zhou W, Chen XD. A study on Bifidobacterium lactis Bb12 viability in bread during baking. Journal of Food Engineering. 2014;122(1):33-37.

[15] Soukoulis C, Yonekura L, Gan HH, Behboudi-Jobbehdar S, Parmenter C, Fisk I. Probiotic edible films as a new strategy for developing functional bakery products: The case of pan bread. Food Hydrocolloids. 2014;39:231-242.

[16] Majeed M, Majeed S, Nagabhushanam K, Natarajan S, Sivakumar A, Ali F. Evaluation of the stability of Bacillus coagulans MTCC 5856 during processing and storage of functional foods. International Journal of Food Science and Technology. 2016;51:894-901.

[17] Wang J, Rosell CM, Barber CB de. Effect of the addition of different fibres on wheat dough performance and bread quality. Food Chemistry. 2002;79(2):221-226.

[18] Izydorczyk MS, Chornick TL, Paulley FG, Edwards NM, Dexter JE. Physicochemical properties of hull-less barley fibre-rich fractions varying in particle size and their potential as functional ingredients in two-layer flat bread. Food Chemistry. 2008;108(2):561-570.

[19] Hu G, Huang S, Cao S, Ma Z. Effect of enrichment with hemicellulose from rice bran on chemical and functional properties of bread. Food Chemistry. 2009;115(3):839-842.

[20] Corral ML, Cerrutti P, Vázquez A, Califano A. Bacterial nanocellulose as a potential additive for wheat bread. Food Hydrocolloids. 2017.

[21] Wang R, Zhou W. Stability of tea catechins in the breadmaking process. Journal of Agricultual \& Food Chemistry. 2004;52(26):8224-8229.

[22] Sivam AS, Sun-Waterhouse D, Waterhouse GIN, Quek S, Perera CO. Physicochemical properties of bread dough and finished bread with added pectin fiber and phenolic antioxidants. Journal of Food Science. 2011;76(3):97-107.

[23] Sui X, Zhang Y, Zhou W. Bread fortified with anthocyanin-rich extract from black rice as nutraceutical sources: Its quality attributes and in vitro digestibility. Food Chemistry. 2016;196:910-916. 
[24] Lucas T. Chapter 19: Baking. In: Zhou W, Hui YH, Leyn I De, M. A. Pagani, C. M. Rosell, J. D. Selman NT, eds. Bakery Products Science and Technology: Second Edition. John Wiley \& Sons, Ltd.; 2014:335-354.

[25] De Vries U, Sluimer P, Bloksma AH. A quantitative model for heat transport in dough and crumb during baking. Cereal Sci. Technol. Sweden, Proc. an Int. Symp. 1989:174-188.

[26] Zhang L, Taal MA, Boom RM, Chen XD, Schutyser MAI. Effect of baking conditions and storage on the viability of Lactobacillus plantarum supplemented to bread. LWT - Food Science \& Technology. 2018;87:318-325.

[27] Hartmann G, Piber M, Koehler P. Isolation and chemical characterisation of water-extractable arabinoxylans from wheat and rye during breadmaking. European Food Research \& Technology. 2005;221:487-492.

[28] Champagne CP, Gardner NJ, Roy D. Challenges in the addition of probiotic cultures to foods. Critical Review of Food Science and Nutrition. 2005;45(1):61-84.

[29] Lakkis JM. Chapter 8: Encapsulation and controlled release in bakery applications. In: Lakkis J, ed. Encapsulation and Controlled Release Technologies in Food Systems, Second Edition. John Wiley \& Sons, Ltd.; 2016:204-235.

[30] Vos P de, Faas MM, Spasojevic M, Sikkema J. Encapsulation for preservation of functionality and targeted delivery of bioactive food components. International Dairy Journal. 2010;20:292302.

[31] Pitigraisorn P, Srichaisupakit K, Wongpadungkiat N, Wongsasulak S. Encapsulation of Lactobacillus acidophilus in moist-heat-resistant multilayered microcapsules. Journal of Food Engineering. 2017;192:11-18.

[32] Cizeikiene D, Juodeikiene G, Paskevicius A, Bartkiene E. Antimicrobial activity of lactic acid bacteria against pathogenic and spoilage microorganism isolated from food and their control in wheat bread. Food Control 2013;31(2):539-545.

[33] Black BA, Zannini E, Curtis JM, Gänzle MG. Antifungal Hydroxy Fatty Acids Produced during Sourdough Fermentation: Microbial and Enzymatic Pathways, and Antifungal Activity in Bread. Applied Environmental Microbiology. 2013;79(6):1866-1873.

[34] Moore MM, Bello FD, Arendt EK. Sourdough fermented by Lactobacillus plantarum FST 1.7 improves the quality and shelf life of gluten-free bread. European Food Research \& Technololgy. 2007;226(6):1309-1316.

[35] Patel AR, Velikov KP. Colloidal delivery systems in foods: A general comparison with oral drug delivery. LWT - Food Science \& Technology. 2011;44(9):1958-1964.

[36] Gökmen V, Ataç B, Barone R, Fogliano V, Kaplun Z. Development of functional bread containing nanoencapsulated omega-3 fatty acids. Journal of Food Engineering. 2011;105(4):585-591.

[37] Curti E, Carini E, Bonacini G, Tribuzio G, Vittadini E. Effect of the addition of bran fractions on bread properties. Journal of Cereal Science. 2013;57(3):325-332.

[38] Izydorczyk MS, Dexter JE. Barley $\beta$-glucans and arabinoxylans: Molecular structure, physicochemical properties, and uses in food products-a Review. Food Research International. 2008;41(9):850-868.

[39] Messia MC, Reale A, Maiuro L, Candigliota T, Sorrentino E, Marconi E. Effects of prefermented wheat bran on dough and bread characteristics. Journal of Cereal Science. 2016;69:138-144. 